\title{
Toll-like receptors play a crucial part in the pathophysiological activity of antiphospholipid antibodies
}

\author{
Philipp von Landenberg
}

Received: 3 May 2011/Accepted: 8 May 2011/Published online: 7 June 2011

(C) Springer-Verlag 2011

\begin{abstract}
The antiphospholipid syndrome (APS) is a systemic autoimmune disease characterized by thrombosis, recurrent fetal loss and the presence of a variety of antiphospholipid antibodies (aPL), directed to phospholipids like Cardiolipin and phospholipid binding proteins like $\beta 2$ glycoprotein I. Till date, the pathophysiological processes underlying these thrombotic events were still not fully understood. Recent data support the idea that the aPL might act via enhanced cytokine release due to activation of certain Toll-like receptors. The investigation of some of those mechanisms in more detail enlightens the involvement of the intracellular receptors TLR7 and TLR8 in a central point. Using patients' IgG fractions and/or monoclonal aPL, either generated from mouse or from human B-cells for the stimulation experiments of monocytes, endothelial cells or dendritic cells, all these stimuli induced an enhanced expression and secretion of cytokines, especially TNF $\alpha$, caused by specific regulation or activation of Toll-like receptors. Using specific agonists or inhibitors could confirm the causal connection of these stimulatory effects. This review focuses on the recent developments connecting the binding of aPL with the activity of Toll-like receptors, especially in monocytes, endothelial cells and dendritic cells.
\end{abstract}

P. von Landenberg

Institut für Klinische Chemie und Laboratoriumsmedizin,

Johannes Gutenberg Universität Mainz, Mainz, Germany

P. von Landenberg $(\bowtie)$

Chefarzt Institut für Labormedizin (IFLM),

Solothurner Spitäler AG, Kantonsspital Olten,

Baslerstrasse 150, 4601 Olten, Switzerland

e-mail: philipp.landenberg@spital.so.ch
Keywords TLR2 - TLR4 - TLR7 - TLR8 ·

Antiphospholipid antibodies $\cdot$ Monocytes

\section{Introduction}

Antiphospholipid syndrome (APS) is a disorder of unknown etiology characterized by venous and/or arterial thrombosis, and by recurrent fetal loss associated with persistently elevated levels of auto antibodies such as antiphospholipid antibodies (aPL) and lupus anticoagulant [1, 2]. The aPL are a part of a heterogeneous family of autoantibodies which react to negatively charged phospholipids such as cardiolipin and phosphatidylserine and to phospholipid binding protein-cofactors like $\beta 2$-gylcoprotein I ( $\beta 2 \mathrm{GPI})$ [3]. The hypercoagulable environment in APS is relatively well known. In contrast, the key role of the up-regulated expression of tissue factor (TF) on the cell surface of monocytes and endothelial cells is a relatively new aspect [4-6]. TF as the main initiation of the coagulation cascade is thought to be the most severe trigger of thrombosis in the pathophysiology of APS [7].

Another recently discussed pathomechanism and subject of currently ongoing studies is the possible involvement of Toll-like receptors (TLRs) in the signaling cascades leading to the clinical symptoms known in the APS [8-16]. TLRs play a crucial role in the early detection of pathogenassociated molecular patterns (PAMPs) and the subsequent activation of the adaptive immune response. In humans, 11 different TLRs have been identified and each TLR appears to recognize distinct PAMPs derived from various microorganisms, including bacteria, viruses, protozoa and fungi [17]. The recognition of microbial components by TLRs results in the activation of a MyD88-dependent cascade (except TLR3) which provokes inflammatory responses. 
Uncontrolled activation of TLRs, however, can lead to substantial inflammation resulting in tissue damage and autoimmunity $[18,19]$. Recent studies demonstrated that nucleic acids of mammalian origin can act as endogenous ligands for TLRs which lead to enhanced secretion of cytokines, mainly interferon alpha (INF $\alpha$ ) by plasmacytoid dendritic cells (pDC). This mechanism is the cause of increased serum concentrations of INF $\alpha$ in systemic lupus erythematosus (SLE) patients which correlate with disease activity and likely contribute to disease pathogenesis [20].

\section{Importance of the tools used for studying the pathogenesis of antiphospholipid antibodies}

To understand the impact of the recently published results by different groups, it seems to be helpful to describe the reagents used to describe the binding of aPL and the respective signaling induced by this binding in certain cells. The most common antibody-preparations used in these studies are presented here in a short overview.

Affinity purified IgG from APS patients specifically directed to $\beta 2 \mathrm{GPI}$

Most used in nearly all studies is the preparation of IgGfractions from APS patient's serum purified using protein $\mathrm{G}$ (or protein A) sepharose columns. As the first step in the purification process, the level of antiphospholipid antibodies directed to $\beta 2 \mathrm{GPI}$ and/or cardiolipin in the APS patient's serum is measured using the standard ELISA methods. After the purification process, the concentration of the specific "antiphospholipid/ $\beta 2 \mathrm{GPI}$ " IgG is significantly enhanced inside the portion of the whole $\operatorname{IgG}$ obtained using this purification method. This approach needs extensive control to exclude unspecific binding of other $\operatorname{IgG}$ specificities in the $\mathrm{IgG}$ preparation.

\section{Affinity purified IgG using $\beta 2$ GPI-coupled columns}

A variant of the methodology described above is the combination of the affinity purification using protein $\mathrm{G}$ (or protein A) sepharose columns with a $\beta 2$ GPI column used in a second step. This approach generates a high purified population of $\beta 2$ GPI-specific IgG antibodies without other, possibly interfering, antibody specificities.

Mouse monoclonals directed to $\beta 2 \mathrm{GPI}$

Monoclonal antibodies offer the possibility to know exactly where, or directed to which antigen, the antibodies are binding. Thus, using mouse monoclonal antibodies might be of great advantage. Nevertheless, it is a problem that the binding characteristics are due to the mouse CDR13 hyper variable binding regions. The best known representative of this antibody species are the monoclonals (HCAL) directed to $\beta 2$ GPI produced by the group of Takao Koike and at present widely used as a standard preparation in the commercial assays.

Human monoclonal antibodies

To overcome the problem of the differences in the binding characteristics of the mouse monoclonal antibodies, it seems to be very promising to work with human monoclonal antibodies. The currently best-characterized monoclonal antibodies are coming from our group. Two protein cofactor independent monoclonal antiphospholipid antibodies (HL5B and HL7G) generated in our group [3] showed a procoagulant activity in monocytes via the induction of TF expression. Both antibodies are of IgG2isotype with lambda light chains and the sequences of their hypervariable regions (CDR3) showed intense somatic mutations. In view of the procoagulant activity induced on monocytes by these monoclonal antibodies, we interpreted HL5B and HL7G to be antigen-maturated antibodies responsible for (some of) the clinical features of APS.

\section{Why Toll-like receptors?}

The initial findings of a study of Sorice et al. [21] demonstrated that human anti- $\beta 2$ GPI antibodies from patients' $\mathrm{IgG}$ fractions induce a proinflammatory and procoagulant monocyte phenotype characterized by the release of TNF $\alpha$ and $\mathrm{TF}$, respectively. Moreover, these results gave some evidence that the antibodies were able to trigger a signal transduction pathway in monocytic cells. In this regard, the first indication derived from the observation that anti$\beta 2$ GPI target antigen was found within lipid rafts, specialized portions of cell plasma membrane implied in signal transduction pathways [21-23], as revealed by the sucrose gradient analysis.

The presence of $\beta 2 \mathrm{GPI}$ dimers in lipid raft fractions was consistent with the observation that oxidized $\beta 2$ GPI was able to trigger signal transduction pathways [24, 25] and that these $\beta 2$ GPI dimers mimic in vitro the effects of $\beta 2$ GPI-anti- $\beta_{2}$ GPI antibody complexes [25]. This hypothesis was further supported by the observation that Annexin A2, which is thought to be the main specific receptor for $\beta 2$ GPI [26], was also highly enriched in lipid raft fractions, where it coimmunoprecipitated with $\beta 2$ GPI. This finding supported the view that the antibodies recognize $\beta 2 \mathrm{GPI}$ that is coupled with its own receptor [12]. This immune complex might then induce cell signaling as suggested by Meroni et al. [9, 12, 22]. 
Following the demonstration that anti- $\beta 2$ GPI antibodies triggered a signaling cascade comparable to that used by TLR4 in endothelial cells, with consequent IRAK phosphorylation and NF- $\kappa \mathrm{B}$ translocation [12], it could be shown that even anti- $\beta 2$ GPI antibodies activated the same pattern in human monocytes as a consequence to the binding of $\beta 2 \mathrm{GPI}$ within lipid rafts.

Furthermore, the previous studies have shown that Annexin A2 mediates EC activation by aPL/anti- $\beta 2$ GPI antibodies after binding to $\beta 2 \mathrm{GPI}[27,28]$. Annexin A2 does not span the cell membrane, so this interaction may also require an "adaptor" protein which is able to transduce it to the intracellular signaling. Accordingly, there is preliminary evidence that TLR4 may be involved as a "coreceptor" for Annexin A2.

Romay-Penabad et al. showed, in agreement with previous observations, that $\beta 2 \mathrm{GPI}$ binds to A2 on target cells recognized by aPL antibodies [29, 30]. The lack of A2 or addition of anti-A2 antibody seemed to produce a significant but incomplete inhibition of some of the pathogenic effects induced by aPL antibodies.

A recent publication of the group of Pierangeli et al. [31] showed impressive results indicating that this Annexin A2 might really play the central role in aPL/anti- $\beta 2$ GPI pathogenic effects in vivo. APL-induced thrombosis, TF activity, and VCAM-1 expression were all significantly diminished in $\mathrm{A} 2^{-/-}$compared with $\mathrm{A} 2^{+/+}$mice. Importantly, the in vivo effects correlated with the inhibitory effect of mouse anti-A2 antibodies on up-regulation of ICAM-1, E-selectin, and TF induced by aPL antibodies in vitro on endothelial cells. These studies were performed using a patient's serum containing anti- $\beta 2 \mathrm{GPI}$ antibodies as well as mouse monoclonal antibodies to $\beta 2 \mathrm{GPI}$ [31].

Compared to the results coming from our group, differences could be demonstrated due to the origin of the employed antibodies. Using human monoclonal antibodies directed to Cardiolipin and Phosphatidylserine in a $\beta 2 \mathrm{GPI}-$ dependent manner, another signaling pathway directed toward TLR7 and TLR8 could be demonstrated.

This human monoclonal antiphospholipid IgG2 kappa monoclonal antibody HL5B binds to pure phospholipids as well as to complexes with $\beta 2$ GPI [3]. Stimulation of monocytes with this antibody revealed enhanced TLR8mediated cytokine secretion and even higher stimulation levels after adding the specific stimulus for TLR8. These effects could be entirely reversed using an inhibitory deoxyoligonucleotide [13]. Testing PBMC's of APS patients for TLR8 mRNA expression level revealed significantly higher amounts of TLR8 in contrast to controls. Moreover, stimulation of human peripheral blood monocytes with $\mathrm{IgG}$ fraction of APS patients showed an increase of TLR8 mRNA expression as well. Furthermore, it could be shown that aPL-induced prothrombotic cytokines via TLR8.
TLR8 is known to be mainly expressed in endosomes of monocytes and neutrophils [32-34] and functions (like TLR7) as a pattern recognition receptor for ssRNA. Although TLR7 and TLR8 seem to be phylogenetically and structurally related, they differ in their target cell selectivity and cytokine induction profile [35].

Meroni et al. [9] suggested as well that TLRs might be involved in the pathogenesis of APS. Their study revealed that $\beta 2$ GPI, which may bind to Annexin II, interacts with TLR4 because of its homology to microbial structures. In turn, aPL binding to this $\beta 2$ GPI might trigger the TLR4 signaling via NF- $\kappa \mathrm{B}$ inducing a proinflammatory and procoagulant phenotype in endothelial cells. Comparable results have been carried out for monocytes [7]. CesarmanMaus et al. [36] were well able to show that antibodies directed against Annexin II had a significant impact on thrombotic events in APS.

Apart from these studies, new evidence arises linking the involvement of TLRs to the pathophysiology of autoimmune diseases. Recently, Subramanian et al. [37] were able to prove that translocation of the TLR7 gene followed by its overexpression is closely associated with the development of SLE in mice.

Taking these findings into consideration, we were able to demonstrate that a human monoclonal aPL (HL5B) as well as IgG fractions from APS patients are able to induce TLR8 (over)expression as well as TNF $\alpha$ and IL- $1 \beta$ release.

It can be assumed that in patients with APS stimulation with increased aPL, the threshold of TLR8 expression in monocytes results in a permanent "overexpression" of TLR8 in peripheral monocytes. This does not necessarily lead to an immediate procoagulant activity, but this could be one reason that "aPL-preactivated" monocytes additionally triggered (2nd Hit) with, e.g., viral RNA, might lead to a higher expression of procoagulant cytokines like $\mathrm{TNF} \alpha[38,39]$ and IL-1 $\beta$ [40] thus, promoting thromboembolic events.

So far, only TLR2 and TLR4 [41] have been associated with APS. A possible correlation between TLR4 and thrombosis in APS has recently been described by Pierangeli et al. [5]. The study reveals that mice with a mutation in the TLR4 gene (therefore LPS-nonresponsive) showed significantly smaller thrombi and a number of adhering leucocytes compared to the control group (LPSresponsive) after injection of aPL IgG-fraction.

TF is mainly expressed in endothelial cells and monocytes [7, 23] and represents one of the most prominent inducers of thrombotic events. Well-described triggers of $\mathrm{TF}$ expression were the procoagulant cytokines TNF $\alpha$ and IL-1 $\beta[42,43]$, which were found as downstream constituents of TLR8 signaling [8, 44].

Enhanced TNF $\alpha$ production after TLR8 stimulation (either with small nuclear RNAs 10 or other TLR 8 agonists 
[35]) has already been reported. Increased levels of IL-1 $\beta$ have only been described in patients with retinal venous occlusion in association with APS so far [45]. Recently, our group could demonstrate that besides the TNF $\alpha$ production, the signaling via TLR8 induced the secretion of IL- $1 \beta$ and the induction of Caspase 1 in monocytes as well [46].

\section{Conclusion}

Current knowledge links the reactivity of aPL to the signaling via Toll-like receptors. Till date, it seems that at least two distinct pathways might be involved in this process depending on the antibody specificity used in the experiments. TLR2/TLR4 as shown by Pierangeli and Meroni group has been clearly linked to the binding of $\beta 2$ GPI-specific antibodies in monocytes and endothelial cells. TLR7/TLR8 seems to be the central players in the signaling cascade induced by aPL directed to cardiolipin/ phosphatidylserine at least in monocytes and dendritic cells. It will be a fascinating challenge to combine these findings and to start, now, a description of a still more conclusive pathogenetical model of the binding of antiphospholipid antibodies to different cell populations.

Conflict of interest The authors declare that they have no conflict of interest related to the publication of this article.

\section{References}

1. Wilson WA, Gharavi AE, Koike T, Lockshin MD, Branch DW, Piette JC, Brey R, Derksen R, Harris EN, Hughes GR, Triplett DA, Khamashta MA (1999) International consensus statement on preliminary classification criteria for definite antiphospholipid syndrome: report of an international workshop. Arthritis Rheum 42:1309-1311

2. Asherson RA (1998) The catastrophic antiphospholipid syndrome, 1998. A review of the clinical features, possible pathogenesis and treatment. Lupus 7(Suppl 2):S55-S62

3. von Landenberg C, Lackner KJ, von Landenberg P, Lang B, Schmitz G (1999) Isolation and characterization of two human monoclonal anti-phospholipid IgG from patients with autoimmune disease. J Autoimmun 13:215-223

4. Lopez-Pedrera C, Buendia P, Aguirre MA, Velasco F, Cuadrado MJ (2006) Antiphospholipid syndrome and tissue factor: a thrombotic couple. Lupus 15:161-166

5. Pierangeli SS, Vega-Ostertag M, Harris EN (2004) Intracellular signaling triggered by antiphospholipid antibodies in platelets and endothelial cells: a pathway to targeted therapies. Thromb Res 114:467-476

6. Wolberg AS, Roubey RA (2004) Mechanisms of autoantibodyinduced monocyte tissue factor expression. Thromb Res 114:391-396

7. Lopez-Pedrera C, Buendia P, Cuadrado MJ, Siendones E, Aguirre MA, Barbarroja N, Montiel-Duarte C, Torres A, Khamashta M, Velasco F (2006) Antiphospholipid antibodies from patients with the antiphospholipid syndrome induce monocyte tissue factor expression through the simultaneous activation of NF-kappaB/ Rel proteins via the p38 mitogen-activated protein kinase pathway, and of the MEK-1/ERK pathway. Arthritis Rheum 54(1):301-311

8. Vollmer J, Tluk S, Schmitz C, Hamm S, Jurk M, Forsbach A, Akira S, Kelly KM, Reeves WH, Bauer S, Krieg AM (2005) Immune stimulation mediated by autoantigen binding sites within small nuclear RNAs involves Toll-like receptors 7 and 8. J Exp Med 202:1575-1585

9. Meroni PL, Raschi E, Testoni C, Parisio A, Borghi MO (2004) Innate immunity in the antiphospholipid syndrome: role of tolllike receptors in endothelial cell activation by antiphospholipid antibodies. Autoimmun Rev 3:510-515

10. Pierangeli SS, Vega-Ostertag ME, Raschi E, Liu X, RomayPenabad Z, De Micheli V, Galli M, Moia M, Tincani A, Borghi MO, Nguyen-Oghalai T, Meroni PL (2007) Toll like receptor 4 is involved in antiphospholipid-mediated thrombosis: in vivo studies. Ann Rheum Dis 66(10):1327-1333

11. Jurk M, Heil F, Vollmer J, Schetter C, Krieg AM, Wagner H, Lipford G, Bauer S (2002) Human TLR7 or TLR8 independently confer responsiveness to the antiviral compound R-848. Nat Immunol 3:499

12. Raschi E, Testoni C, Bosisio D, Borghi MO, Koike T, Mantovani A, Meroni PL (2003) Role of the MyD88 transduction signaling pathway in endothelial activation by antiphospholipid antibodies. Blood 101:3495-3500

13. Barrat FJ, Meeker T, Gregorio J, Chan JH, Uematsu S, Akira S, Chang B, Duramad O, Coffman RL (2005) Nucleic acids of mammalian origin can act as endogenous ligands for Toll-like receptors and may promote systemic lupus erythematosus. J Exp Med 202:1131-1139

14. Christensen SR, Shupe J, Nickerson K, Kashgarian M, Flavell RA, Shlomchik MJ (2006) Toll-like receptor 7 and TLR9 dictate autoantibody specificity and have opposing inflammatory and regulatory roles in a murine model of lupus. Immunity 25:417-428

15. Ehlers M, Fukuyama H, McGaha TL, Aderem A, Ravetch JV (2006) TLR9/MyD88 signaling is required for class switching to pathogenic IgG2a and $2 b$ autoantibodies in SLE. J Exp Med 203:553-561

16. Leadbetter EA, Rifkin IR, Hohlbaum AM, Beaudette BC, Shlomchik MJ, Marshak-Rothstein A (2002) Chromatin-IgG complexes activate B cells by dual engagement of IgM and Tolllike receptors. Nature 416:603-607

17. Akira S, Uematsu S, Takeuchi O (2006) Pathogen recognition and innate immunity. Cell 124:783-801

18. Andreakos E, Foxwell B, Feldmann M (2004) Is targeting Tolllike receptors and their signaling pathway a useful therapeutic approach to modulating cytokine-driven inflammation? Immunol Rev 202:250-265

19. Rifkin IR, Leadbetter EA, Busconi L, Viglianti G, MarshakRothstein A (2005) Toll-like receptors, endogenous ligands, and systemic autoimmune disease. Immunol Rev 204:27-42

20. Krieg AM (2007) The toll of too much TLR7. Immunity 27:695-697

21. Sorice M, Longo A, Capozzi A, Garofalo T, Misasi R, Alessandri C, Conti F, Buttari B, Riganò R, Ortona E, Valesini G (2007) Anti-beta2-glycoprotein I antibodies induce monocyte release of tumor necrosis factor alpha and tissue factor by signal transduction pathways involving lipid rafts. Arthritis Rheum 56(8):2687-2697

22. Hakomori S, Handa K, Iwabuchi K, Yamamura S, Prinetti A (1998) New insights in glycosphingolipid function: signaling domain, a cell surface assembly of glycosphingolipids with signal transducer molecules, involved in cell adhesion coupled with signaling. Glycobiology 8(10):xi-ix 
23. Meroni PL, Raschi E, Testoni C, Borghi MO (2004) Endothelial cell activation by antiphospholipid antibodies. Clin Immunol 112:169-174

24. Buttari B, Profumo E, Mattei V, Siracusano A, Ortona E, Margutti P et al (2005) Oxidized 2-glycoprotein I induces human dendritic cell maturation and promotes a $\mathrm{T}$ helper type 1 response. Blood 106:3880-3887

25. Lutters BC, Derksen RH, Tekelenburg WL, Lenting PJ, Arnout J, de Groot P (2003) Dimers of 2-glycoprotein I increase platelet deposition to collagen via interaction with phospholipids and the apolipoprotein E receptor 2. J Biol Chem 278:33831-33838

26. Ma K, Simantov R, Zhang JC, Silverstein R, Hajjar KA, McCrae KR (2000) High affinity binding of 2-glycoprotein I to human endothelial cells is mediated by annexin II. J Biol Chem 275:15541-15548

27. Muzio M, Natoli G, Saccani S, Levrero M, Mantovani A (1998) The human toll signaling pathway: divergence of NF-kB and JNK/SAPK activation upstream of TRAF6. J Exp Med 187:2097-3101

28. Medzhitov R, Preston-Hurlburt P, Kopp A et al (1999) MyD88 is an adaptor protein in the hToll/IL-1 receptor family signaling pathways. Mol Cell. 2:253-258

29. Cervera R, Piette JC, Font J, Euro-Phospholipid Project Group et al (2002) Antiphospholipid syndrome: clinical and immunologic manifestations and patterns of disease expression in a cohort of 1,000 patients. Arthitis Rheum 46:1019-1027

30. Blank M, Krause I, Fridkin M et al (2002) Bacterial induction of autoantibodies to 2-glycoprotein-1 accounts for the infectious etiology of antiphospholipid syndrome. $\mathbf{J}$ Clin Invest 109:797-804

31. Romay-Penabad Z, Montiel-Manzano MG, Shilagard T, Papalardo E, Vargas G, Deora AB, Wang M, Jacovina AT, GarciaLatorre E, Reyes-Maldonado E, Hajjar KA, Pierangeli SS (2009) Annexin A2 is involved in antiphospholipid antibody-mediated pathogenic effects in vitro and in vivo. Blood 114(14):3074-3083 (Epub 2009 Jul 23)

32. Wang J, Shao Y, Bennett TA, Shankar RA, Wightman PD, Reddy LG (2006) The functional effects of physical interactions among Toll-like receptors 7, 8, and 9. J Biol Chem 281:37427-37434

33. Hornung V, Rothenfusser S, Britsch S et al (2002) Quantitative expression of toll-like receptor 1-10 mRNA in cellular subsets of human peripheral blood mononuclear cells and sensitivity to $\mathrm{CpG}$ oligodeoxynucleotides. J Immunol 168:4531-4537

34. Nagase H, Okugawa S, Ota Y et al (2003) Expression and function of Toll-like receptors in eosinophils: activation by Tolllike receptor 7 ligand. J Immunol 171:3977-3982
35. Gorden KB, Gorski KS, Gibson SJ et al (2005) Synthetic TLR agonists reveal functional differences between human TLR7 and TLR8. J Immunol 174:1259-1268

36. Cesarman-Maus G, Rios-Luna NP, Deora AB et al (2006) Autoantibodies against the fibrinolytic receptor, annexin 2, in antiphospholipid syndrome. Blood 107:4375-4382

37. Subramanian S, Tus K, Li QZ et al (2006) A Tlr7 translocation accelerates systemic autoimmunity in murine lupus. Proc Natl Acad Sci USA 103:9970-9975

38. Berman J, Girardi G, Salmon JE (2005) TNF-alpha is a critical effector and a target for therapy in antiphospholipid antibodyinduced pregnancy loss. J Immunol 174:485-490

39. Forastiero RR, Martinuzzo ME, de Larranaga GF (2005) Circulating levels of tissue factor and proinflammatory cytokines in patients with primary antiphospholipid syndrome or leprosy related antiphospholipid antibodies. Lupus. 14:129-136

40. Bernot D, Peiretti F, Canault M, Juhan-Vague I, Nalbone G (2005) Upregulation of TNF-alpha-induced ICAM-1 surface expression by adenylate cyclase-dependent pathway in human endothelial cells. J Cell Physiol 202:434-441

41. Giannakopoulos B, Passam F, Rahgozar S, Krilis SA (2007) Current concepts on the pathogenesis of the antiphospholipid syndrome. Blood 109:422-430

42. Hezi-Yamit A, Wong PW, Bien-Ly N et al (2005) Synergistic induction of tissue factor by coagulation factor Xa and TNF: evidence for involvement of negative regulatory signaling cascades. Proc Natl Acad Sci USA 102:12077-12082

43. Bevilacqua MP, Pober JS, Majeau GR, Fiers W, Cotran RS, Gimbrone MA Jr (1986) Recombinant tumor necrosis factor induces procoagulant activity in cultured human vascular endothelium: characterization and comparison with the actions of interleukin 1. Proc Natl Acad Sci USA 83:4533-4537

44. Cekaite L, Furset G, Hovig E, Sioud M (2007) Gene expression analysis in blood cells in response to unmodified and 2 -modified siRNAs reveals TLR-dependent and independent effects. J Mol Biol 365:90-108

45. Ilhan F, Celiker U, Godekmerdan A, Kan E (2005) The antiphospholipid antibody syndrome research in patients with retinal venous occlusion. Arch Med Res 36:372-375

46. Hurst J, Prinz N, Lorenz M, Bauer S, Chapman J, Lackner KJ, von Landenberg P (2009) TLR7 and TLR8 ligands and antiphospholipid antibodies show synergistic effects on the induction of IL-1beta and caspase- 1 in monocytes and dendritic cells. Immunobiology 214(8):683-691 